\title{
PENINGKATAN DAYA SAING UMKM DI ERA NEW NORMAL MELALUI STRATEGI PEMBUATAN KONTEN PROMOSI DIGITAL
}

\author{
Hera Febria Mavilinda ${ }^{1}$ \\ Fakultas Ekonomi, Universitas Sriwijaya \\ email: herafebria@fe.unsri.co.id \\ Akhmad Nazaruddin ${ }^{2}$ \\ Fakultas Ekonomi, Universitas Sriwijaya \\ email: akhmadnazaruddin@fe.unsri.ac.id \\ Islahuddin Daud ${ }^{3}$ \\ Fakultas Ekonomi, Universitas Sriwijaya \\ email: islahuddindaud@fe.unsri.ac.id \\ Muhammad Ichsan Siregar ${ }^{4}$ \\ Fakultas Ekonomi, Universitas Sriwijaya \\ email: ichsansiregar@fe.unsri.ac.id
}

\begin{abstract}
ABSTRAK
Pada Era New Normal penggunaan platform digital media sosial seperti Instagram dan facebook menjadi pilihan yang tepat bagi para pelaku Unit Usaha Mikro Kecil Menengah (UMKM) untuk memasarkan produknya. Agar UMKM dapat sukses mempromosikan produknya secara online, pelaku UMKM perlu merancang strategi pemasaran berbasis digital (Digital Marketing) diantaranya melalui pembuatan konten promosi digital. Permasalahan yang terjadi saat ini adalah masih rendahnya kemampuan para pelaku UMKM dalam memasarkan produknya pada platform digital. Kurangnya pengetahuan para pelaku UMKM dalam membuat konten promosi digital menjadi penyebab dari rendahnya daya saing UMKM dalam konteks pemasaran digital. Kondisi tersebut juga terjadi pada UMKM yang ada di Kota Palembang, dimana masih banyak pelaku UMKM di Kota Palembang yang belum memanfaatkan platform digital sebagai media promosi online karena keterbatasan pengetahuan dan kemampuannya. Merujuk pada kondisi tersebut, kegiatan pengabdian kepada masyarakat ini dilakukan untuk memberikan edukasi dalam bentuk pelatihan kepada para pelaku UMKM mengenai cara merancang strategi pembuatan konten promosi digital. Sehingga diharapkan melalui pelatihan ini dapat meningkatkan kemampuan UMKM dalam merancang strategi pembuatan konten promosi digital untuk menarik minat pembelian konsumen dan meningkatkan kembali volume penjualan yang mengalami penurunan akibat dampak pandemi tersebut, sekaligus meningkatkan daya saing nya dalam mempertahankan bisnis di Era New Normal.
\end{abstract}

Kata Kunci : Konten Promosi Digital, Strategi Pemasaran Digital, UMKM

Increasing The Competitiveness of MSME'S in The New Normal Era Through The Strategy Of Creating Digital Promotion Content

\begin{abstract}
In the New Normal Era, the use of social media digital platforms such as Instagram and Facebook is the right choice for Micro, Small and Medium Enterprises (MSMEs) to promotes their products. In order for MSMEs to be successful in promoting their products online, MSME need to design digital-based marketing strategies (Digital Marketing), including by creating digital
\end{abstract}


promotional content. The problem that occurs today is the low ability of MSME in marketing their products on digital platforms. The lack of knowledge of MSME in creating digital promotional content is the cause of the low competitiveness of MSMEs in the context of digital marketing. This condition also occurs in MSMEs in Palembang City, where there are still many MSMEs in Palembang City who have not used digital platforms as online promotion media because of their limited knowledge and abilities. Referring to these conditions, this community service activity is carried out to provide education in the form of training to MSME on how to design strategies for creating digital promotional content. So it is hoped that through this training it can improve the ability of MSMEs in designing strategies for creating digital promotional content to attract consumer purchases and increase the volume of sales that have decreased due to the impact of the pandemic, as well as increase their competitiveness in maintaining business in the New Normal Era.

\section{Keywrods : Digital Promotional Content, Digital Marketing Strategy, MSMEs}

\section{PENDAHULUAN}

Situasi pandemi akibat wabah Corona Virus Disease 2019 (COVID-19) yang telah melanda hampir di seluruh dunia sejak akhir tahun 2019 telah berdampak besar terhadap segala aspek kehidupan di segala bidang. Dampak yang paling besar dirasakan adalah dalam bidang ekonomi. Indonesia merupakan salah satu negara yang turut merasakan dampak negatif di bidang ekonomi akibat dari wabah pandemi tersebut. Hal ini tercermin dari tingkat pertumbuhan ekonomi di Indonesia yang terus mengalami perlambatan.

Berdasarkan data dari Badan Pusat Statistik (BPS) pada kuartal II tahun 2020 pertumbuhan ekonomi mengalami penurunan atau kontraksi sebesar $-5,32 \%$ YOY, ekonomi Indonesia triwulan II-2020 terhadap triwulan sebelumnya terkontraksi sebesar- 4,19\% (q-toq), dan ekonomi Indonesia semester I-2020 terhadap semester I-2019 terkontraksi 1,26\% (cto-c) (Sumber : BPS, 2020). Salah satu faktor penyumbang penurunan pertumbuhan ekonomi tersebut diantaranya adalah tren penurunan konsumsi masyarakat yang memburuk pada kisaran 2,84\% dibandingkan kondisi sebelum pandemi yang dapat tumbuh rata-rata hingga 5\%, padahal hampir 57\% atau setara setara Rp.9.000 Trilun PDB Indonesia sebagai indikator pertumbuhan ekonomi dikontribusi oleh tingkat konsumsi masyarakat. (Sumber : Tirto.id, 2020). Tingkat konsumsi masyarakat yang terus mengalami penurunan selama masa pandemi Covid 19 merupakan dampak dari kebijakan pemerintah sebagai langkah penanggulangan dalam memutus mata rantai penyebaran Covid 19 diantaranya melalui kebijakan Pembatasan Sosial Berskala Besar (PSBB) yang membatasi aktivitas masyarakat di luar rumah dengan melakukan work from home (WFH), School From Home (SFH), social distancing dan physical distancing.

Akibat dari kebijakan pemerintah untuk membatasi aktivitas masyarakat selama masa pandemi Covid 19 juga turut memberikan dampak yang signifikan terhadap perkembangan sektor bisnis di Indonesia termasuk sektor Usaha Mikro Kecil Menengah (UMKM). Berdasarkan data center dari Kementrian Koperasi dan UKM bahwa penjualan produk UMKM mengalami penurunan yang cukup signifikan yaitu sebesar $57 \%$ selama masa pandemi Covid 19. Sedangkan dari hasil survei daring Lembaga Ilmu Pengetahuan Indonesia (LIPI) yang melibatkan lebih dari 600 responden menunjukkan bahwa sebanyak 75\% UMKM mengalami penurunan penjualan yang siginifikan pada masa pandemi Covid 19 (Sumber : Liputan6.com).

Dampak negatif dari situasi pandemi juga dirasakan oleh UMKM yang ada di Kota Palembang, dimana dari 163.291 pelaku UMKM yang ada di Kota Palembang sekitar 12.00 UMKM atau 7,3\% mengalami keterpurukan bahkan menutup usahanya baik untuk sementara maupun secara permanen akibat pandemi Covid 19 (Sumber : Kompas.id, 2020). Sedangkan data pemerintah kota Palembang mencatat bahwa ada sekitar 35 ribu 
UMKM yang mengalami penurunan Omset sejak pandemi COVID-19 (Sumber : Kompas.TV, 2020).

Pasca masa pandemi Covid 19, masyarakat dihadapkan dengan suatu tatanan normal baru atau Era New Normal. Pada Era New Normal hampir sebagian besar kegiatan atau aktivitas masyarakat melibatkan teknologi internet termasuk dalam perilaku pembelian konsumen sebagai konsekuensi dari terbatasnya aktivitas manusia untuk keluar rumah. Hal ini membuat sektor bisnis harus dapat segera beradaptasi dan bertransformasi pada platform digital untuk dapat mempertahankan bisnis nya dan meningkatkan kembali penjualan produknya di Era New Normal. Penggunaan platform digital media sosial seperti Instagram dan facebook menjadi pilihan yang tepat bagi para UMKM untuk memasarkan produknya di Era New Normal saat ini karena selain menawarkan kemudahan akses dan efisiensi biaya, media sosial merupakan Platform digital yang paling banyak diakses oleh masyarakat untuk berkomunikasi dan berinteraksi selama masa pandemi covid 19. Berdasarkan data dari Katadata, penggunaan platform media sosial seperti Instagram dan facebook mengalami lonjakan hingga lebih dari $40 \%$ selama masa pandemi. (Sumber : Katadata, 2020).

Penggunaan platform digital melalui media sosial yang mengalami lonjakan tersebut dapat menjadi peluang sekaligus tantangan bagi para pelaku UMKM dalam memanfaatkan platform digital sebagai media promosi online di Era New Normal. Agar UMKM dapat sukses mempromosikan produknya secara online, para pelaku UMKM perlu merancang strategi pemasaran berbasis digital atau yang dikenal dengan istilah pemasaran digital (Digital Marketing) untuk menarik minat konsumen dalam melakukan pembelian produk sehingga dapat meningkatkan volume penjualan diantaranya melalui pembuatan konten promosi digital. Hal ini ditegaskan dalam hasil penelitian Kee dan yazdanifard (2015) yang menyatakan bahwa konten promosi merupakan salah satu bentuk strategi pemasaran yang dapat mempengaruhi keputusan pembelian konsumen. Konten promosi merupakan strategi pemasaran dimana pemasar merencanakan, membuat dan mendistribusikan konten yang mampu menarik konsumen dan mendorong mereka melakukan pembelian. Konten promosi membuat konsumen menyadari kekuatan pengetahuan dan informasi terkait produk yang ditawarkan pemasar yang dapat mengakibatkan keputusan pembelian yang lebih baik dan dapat meningkatkan penjualan produk di masa yang akan datang. Konten promosi dapat menjadi salah satu strategi pemasaran digital bagi UMKM dalam mempertahankan bisnis nya di masa pandemi covid 19 .

Namun demikian, permasalahan yang terjadi saat ini adalah masih rendahnya kemampuan para pelaku UMKM dalam memasarkan produknya pada platform digital bahkan masih banyak pelaku UMKM yang mengalami kesulitan dalam menggunakan fiturfitur dari platform digital tersebut. Kurangnya

pengetahuan dari para pelaku UMKM dalam membuat konten promosi digital untuk melakukan pemasaran produk secara online dan masih rendahnya pengembangan kewirausahaan digital di Indonesia menjadi penyebab dari lemahnya daya saing UMKM dalam konteks pemasaran digital. (Mavilinda, H.F et al, 2021).

Berdasarkan data yang dimiliki

Kementrian dan E- Commerce menunjukkan bahwa keberhasilan UMKM pada pemasaran online masih cukup rendah yaitu antara 4 $10 \%$, penyebabnya adalah masih lemahnya strategi promosi yang digunakan oleh para UMKM diantaranya konten promosi produk yang tidak kreatif dan terkesan kaku (monoton) sehingga kurang efektif menarik minat konsumen secara besar dan mempengaruhi keputusan pembeliannya, lebih lanjut Menteri Koperasi dan UMKM menyatakan bahwa para pelaku UMKM belum memiliki keahlian yang memadai dalam melakukan strategi promosi digital (Sumber : Liputan6.com, 2020).

Kondisi tersebut juga terjadi pada UMKM yang ada di Kota Palembang, dimana masih banyak pelaku UMKM di Kota Palembang yang belum memanfaatkan platform digital sebagai media promosi dalam memasarkan produknya secara online karena keterbatasan pengetahuan dan kemampuannya, Pengamat ekonomi Sumatera Selatan menyatakan bahwa UMKM di Kota Palembang yang aktif dalam 
menggunakan platform digital di media sosial untuk mempromosikan produknya secara online baru mencapai 8\% dari 3,97 juta keseluruhan pengguna platform digital (Sumber : Sumsel.idntimes.com, 2020). Berdasarkan latar belakang diatas, maka rumusan masalah yang dapat didentifikasi adalah :

1. Masih rendahnya pengetahuan dan kompetensi pelaku UMKM di Kota Palembang dalam membuat konten promosi digital sebagai bentuk strategi pemasaran untuk mempertahankan bisnis di Era New Normal.

2. Fenomena pandemi covid 19 memberikan dampak yang signifikan terhadap menurunnya omset penjualan bagi para pelaku UMKM khususnya yang ada di Kota Palembang.

\section{METODE PELAKSANAAN}

Khalayak sasaran kegiatan pengabdian masyarakat yang dipilih adalah para pelaku UMKM yang ada di Kota Palembang sebanyak 30 orang, dengan kriteria telah memiliki usaha berskala mikro kecil menengah yang sedang berjalan dan berada di Kota Palembang. Jenis usaha pelaku UMKM dapat bergerak di berbagai bidang seperti bidang kuliner/makanan, pakaian, jasa dan lain sebagainya.

Pelaksanaan kegiatan Pengabdian Pada Masyarakat ini dilakukan menggunakan metode konvensional (pelaksanaan kegiatan secara offline) dengan tetap menerapkan protokol kesehatan dalam pelaksanaannya. Adapun metode konvensional ini dilaksanakan dalam bentuk ceramah/presentasi, pembagian materi dan diskusi. Berikut ini sistematika pelaksanaan kegiatan pengabdian yang dilakukan adalah sebagai berikut :

\section{a. Langkah 1 (Metode Ceramah)}

Peserta diberikan pengetahuan dan pemahaman mengenai kondisi bisnis di Era New Normal, pemanfaatan platform digital sebagai media promosi dan strategi pembuatan konten promosi yang efektif pada platform digital untuk dapat meningkatkan daya saing dalam mempertahankan bisnis di Era New Normal.

\section{b. Langkah 2 (Metode Tutorial)}

Peserta diberikan materi mengenai Teknik pembuatan konten promosi yang efektif pada platform digital dan merancang strategi pembuatan konten promosi digital untuk bisnisnya.

\section{c. Langkah 3 (Metode Diskusi)}

Peserta pelatihan diberikan kesempatan untuk mendiskusikan permasalahan yang dihadapi dalam pembuatan konten promosi digital dan pengalaman mereka dalam membuat konten promosi digital untuk memasarkan produknya secara online.

\section{d. Langkah 4 (Evaluasi)}

Beberapa rangkaian kegiatan evaluasi yang dilakukan untuk menilai keberhasilan kegiatan pengabdian masyarakat ini adalah meliputi sebagai berikut :

1. Selama kegiatan pengabdian berlangsung, peserta diberikan kesempatan untuk bertanya mengenai hal-hal yang belum dipahami terkait strategi dalam pembuatan konten promosi digital.

2. Pada akhir kegiatan pengabdian, akan dilakukan review secara menyeluruh mengenai strategi pembuatan konten promosi digital. Review tersebut dengan melakukan tanya jawab kepada seluruh peserta pelatihan untuk melihat tingkat pemahaman peserta setelah pelatihan dilaksanakan.

3. Peserta pelatihan diberikan lembar kuisioner evaluasi untuk memberikan penilaian terhadap penyelenggaraan kegiatan pengabdian masyarakat mengenai peningkatan daya saing UMKM dalam mempertahankan bisnis di Era New Normal melalui pelatihan strategi pembuatan konten promosi digital. 


\section{HASIL DAN PEMBAHASAN \\ Hasil Pelaksanaan Kegiatan}

Kegiatan pengabdian kepada masyarakat yang berjudul "Peningkatan Daya Saing UMKM Dalam Mempertahankan Bisnis di Era New Normal Melalui Strategi Pembuatan Konten Promosi Pada Platform Digital" telah dilaksanakan pada hari Senin tanggal 09 November 2020 di Kantor Camat Ilir Barat II Kota Palembang. Kegiatan penyuluhan ini telah dihadiri oleh \pm 30 peserta yang merupakan kelompok UMKM yang ada di Kecamatan Ilir Barat II Kota Palembang dengan jenis usaha yang bergerak di bidang Kuliner, Souvenir dan Konveksi. Kegiatan pengabdian masyarakat ini dilaksanakan dengan tetap memperhatikan protokol kesehatan, dimana para peserta yang hadir wajib menggunakan masker yang telah dibagikan oleh panitia, mengecek suhu tubuh para peserta dan mengatur jarak tempat duduk peserta. Adapun Kegiatan pengabdian kepada masyarakat ini terdiri dari beberapa agenda yaitu :

\section{Acara Pembukaan}

Kegiatan pengabdian kepada masyarakat ini dimulai dengan acara pembukaan yang berupa kata sambutan dari Camat Ilir Barat II Kota Palembang. Dalam sambutannya Camat Ilir Barat II Kota Palembang menyampaikan bahwa kegiatan pengabdian masyarakat ini adalah yang pertama kali dilakukan di Kecamatan Ilir Barat II Palembang, dimana saat ini ada sekitar lebih dari 50 (lima puluh) UMKM yang ada di Kecamatan Ilir Barat II dengan mayoritas jenis usahanya bergerak di bidang kuliner.

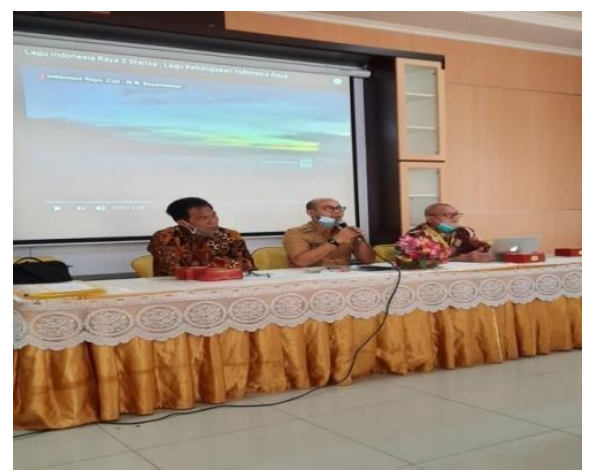

Gambar 1. Acara Pembukaan

\section{Acara Pelatihan Berupa Penyampaian Materi Oleh Nara Sumber.}

Acara pelatihan ini dibuka oleh ketua pelaksana kegiatan pengabdian masyarakat yaitu Ibu Hera Febria Mavilinda SE., M.Si sekaligus sebagai nara sumber yang akan menyampaikan materi mengenai "Strategi Pembuatan Konten Promosi Digital”.

Adapun materi yang disampaikan oleh narasumber diantaranya mengenai :

a. Definisi dan Ruang Lingkup Pemasaran

Digital.

b. Pengertian Konten Promosi.

c. Jenis-Jenis Platform Digital.

d. Strategi Pembuatan Konten Promosi

Digital.

e. Cara Mengatur Jadwal Konten Promosi

Yang Baik.

f. Cara Membuat Kalimat Promosi.

g. Hal-Hal Penting Yang Perlu

diperhatikan Dalam Membuat Konten

Pada Platform Media Sosial.

Setelah narasumber selesai menyampaikan materi, anggota dan panitia pelaksana kegiatan pengabdian masyarakat ini membuka sesi diskusi dan tanya jawab kepada para peserta. Dalam sesi diskusi dan tanya jawab ini, para pelaku UMKM terlibat aktif untuk bertanya dan menggali informasi mengenai teknik membuat konten promosi digital. Selanjutnya setelah sesi diskusi dan tanya jawab selesai dilaksanakan, dilanjutkan dengan sesi foto Bersama dengan seluruh peserta pelatihan sebagai bentuk dokumentasi dari kegiatan pengabdian yang telah dilaksanakan.

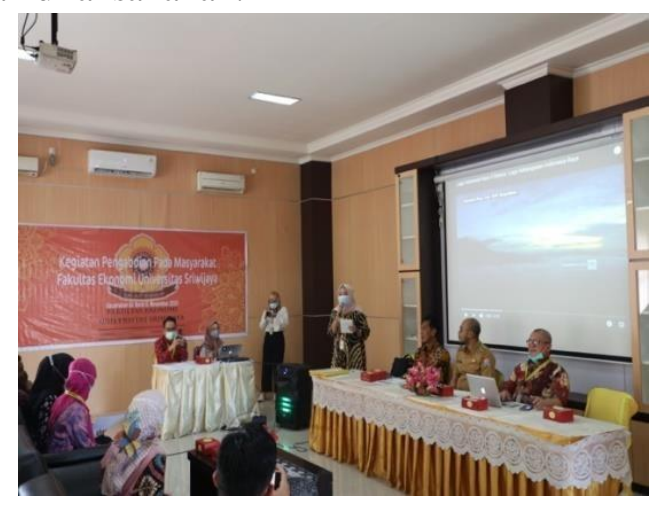

Gambar 2. Penyampaian Materi 


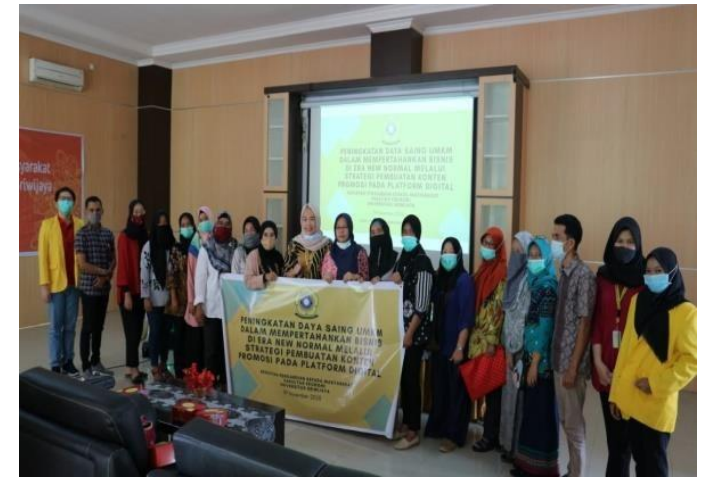

Gambar 3. Foto Bersama Peserta

\section{Evaluasi Kegiatan}

Setelah pelatihan ini dilakukan, para peserta menyatakan komitmen mereka untuk mengimplementasikan ilmu yang diperoleh dari pelatihan ini agar dapat mengembangkan strategi dalam pembuatan konten promosi digital yang efektif untuk menarik minat pembelian konsumen online dan meningkatkan kembali volume penjualan mereka.

Di akhir acara, nara sumber melakukan review kembali terhadap materi yang telah disampaikan dengan memberikan beberapa pertanyaan secara lisan kepada para peserta terkait dengan bagaimana strategi dalam pembuatan konten promosi digital, dimana 4 dari 5 pertanyaan yang diberikan oleh nara sumber kepada para peserta dapat dijawab dengan tepat dan benar.

Selain itu para peserta juga diberikan latihan untuk membuat draft rancangan strategi dalam promosi digital berdasarkan jenis usahanya masing-masing. Berdasarkan hasil evaluasi dari draft rancangan strategi promosi digital yang telah dibuat $70 \%$ peserta memperoleh penilaian sangat baik, $20 \%$ memperoleh penilaian Baik dan $10 \%$ memperoleh penilaian cukup baik. Evaluasi materi yang diberikan oleh nara sumber kepada para peserta bertujuan untuk melihat seberapa besar tingkat pemahaman peserta terhadap materi yang telah disampaikan. Dari hasil evaluasi materi yang telah dilakukan $90 \%$ peserta telah memahami dan mengetahui bagaiman strategi dalam pembuatan konten promosi digital.

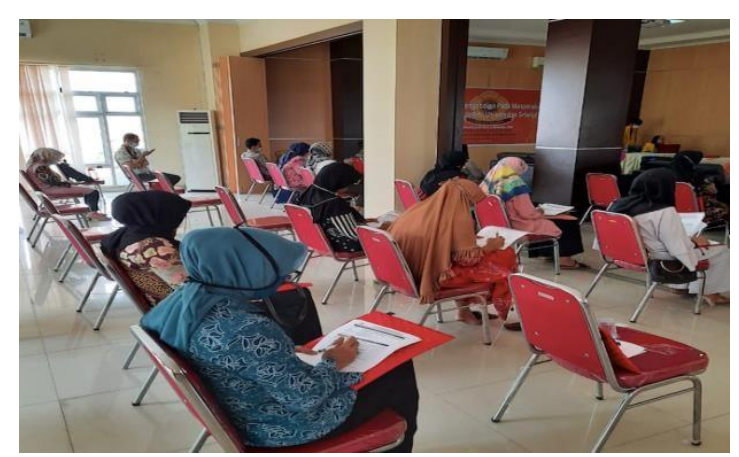

Gambar 4. Kegiatan Evaluasi Peserta

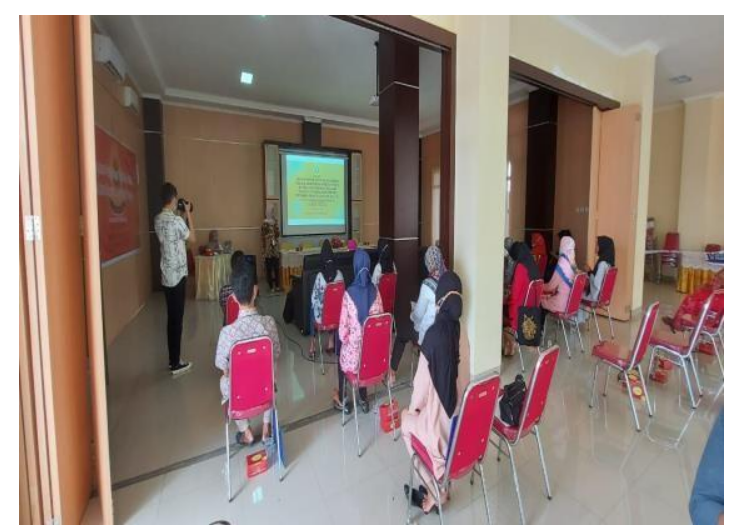

Gambar 5. Kegiatan Evaluasi Peserta

Setelah melakukan review materi, para peserta pelatihan dibagikan lembar kuisioner evaluasi yang berisi penilaian oleh peserta terhadap pelaksanaan kegiatan pengabdian masyarakat yang telah dilakukan. Lembar kuisioner evaluasi dibagi kedalam 4 skala yang terdiri dari Sangat Setuju (SS), Setuju (S), Tidak Setuju (TS) dan Sangat Tidak Setuju (STS). Kegiatan evaluasi tersebut penting untuk mengetahui feedback dan manfaat yang dirasakan oleh para peserta serta kritik dan saran atas penyelenggaraan kegiatan pengabdian ini, dimana hal ini akan menjadi bahan evaluasi bagi panitia untuk penyelenggaraan kegiatan pengabdian masyarakat di masa yang akan datang. Adapun hasil kuisioner evaluasi dapat dilihat pada Tabel 1 berikut ini : 
Tabel 1. Hasil Kuisioner Evaluasi

\begin{tabular}{|c|c|c|c|c|c|}
\hline No & Pernyataan & SS & $\mathrm{S}$ & TS & STS \\
\hline 1 & $\begin{array}{l}\text { Materi yang } \\
\text { disampaikan sangat } \\
\text { bermanfaat untuk } \\
\text { mengembangkan } \\
\text { usaha saya }\end{array}$ & 25 & 5 & 0 & 0 \\
\hline 2 & $\begin{array}{lr}\text { Materi } & \text { yang } \\
\text { disampaikan } & \text { dapat } \\
\text { meningkatkan } & \\
\text { kemampuan } & \text { saya } \\
\text { dalam menjalankan } & \\
\text { bisnis } & \\
\end{array}$ & 20 & 10 & 0 & 0 \\
\hline 3 & $\begin{array}{l}\text { Saya Merasa puas } \\
\text { terhadap pelaksanaan } \\
\text { kegiatan pengabdian } \\
\text { ini }\end{array}$ & 27 & 3 & 0 & 0 \\
\hline 4 & $\begin{array}{l}\text { Setelah mengikuti } \\
\text { pelatian ini saya dapat } \\
\text { memahami bagaimana } \\
\text { strategi pembuatan } \\
\text { konten promosi digital } \\
\text { untuk memasarkan } \\
\text { produk secara online }\end{array}$ & 18 & 12 & 0 & 0 \\
\hline 5 & $\begin{array}{l}\text { Panitia sigap dalam } \\
\text { menanggapi } \\
\text { pertanyaan yang } \\
\text { diajukan oleh para } \\
\text { peserta }\end{array}$ & 22 & 8 & 0 & 0 \\
\hline
\end{tabular}

Berdasarkan dari hasil jawaban responden pada Tabel 1 diatas, dapat diketahui bahwa pada pernyataan pertama terdapat 25 peserta atau sebanyak $83,3 \%$ peserta menyatakan sangat setuju dan 5 peserta atau sebanyak $16,6 \%$ menyatakan setuju bahwa materi yang disampaikan sangat bermanfaat untuk mengembangkan usaha mereka. Pada pernyataan kedua terdapat 20 peserta atau sebanyak $66,67 \%$ peserta menyatakan sangat setuju dan 10 peserta atau sebanyak 33,33\% peserta menyatakan setuju bahwa materi yang disampaikan dapat meningkatkan kemampuan peserta dalam menjalankan bisnisnya. Pada pernyataan ketiga terdapat 27 peserta atau sebanyak $90 \%$ peserta menyatakan sangat setuju dan 3 peserta atau sebanyak $10 \%$ peserta menyatakan setuju bahwa mereka merasa puas terhadap pelaksanaan kegiatan pengabdian masyarakat ini. Pada pernyataan keempat terdapat 18 peserta atau sebanyak $60 \%$ peserta menyatakan sangat setuju dan 12 peserta atau sebanyak $40 \%$ peserta menyatakan setuju bahwa setelah mengikuti pelatihan ini peserta dapat memahami bagaimana strategi dalam pembuatan konten promosi digital untuk memasarkan produk secara online. Pada pernyataan kelima terdapat 22 peserta atau sebanyak $73,33 \%$ peserta menyatakan sangat setuju dan 8 peserta atau sebanyak 26,67\% peserta menyatakan setuju bahwa panitia sigap dalam menanggapi pertanyaan yang diajukan.

Dari hasil keseluruhan evaluasi kegiatan pengabdian masyarakat ini dapat diketahui bahwa materi yang disampaikan sangat bermanfaat dalam mengedukasi dan meningkatkan kemampuan para pelaku UMKM yang menjadi peserta pengabdian ini terkait dengan strategi pembuatan konten promosi digital.

\section{Pembahasan}

Permasalahan yang diangkat dalam kegiatan pengabdian masyarakat ini adalah masih rendahnya kemampuan para pelaku UMKM dalam memasarkan produknya pada platform digital bahkan masih banyak pelaku UMKM yang mengalami kesulitan dalam menggunakan fitur-fitur dari platform digital tersebut.

Merujuk pada kondisi atas, kegiatan pengabdian kepada masyarakat mengenai strategi pembuatan konten promosi digital dilakukan untuk memberikan edukasi dalam bentuk pelatihan kepada para pelaku UMKM mengenai cara merancang strategi pembuatan konten promosi pada platform digital, cara membuat kalimat promosi yang menarik, cara mengatur jadwal konten promosi pada platform digital serta hal-hal yang perlu diperhatikan untuk membuat konten promosi.

Berdasarkan hasil pelaksanaan kegiatan pengabdian masyarakat ini, mayoritas para pelaku UMKM yang ada di Kecamatan Ilir Barat II Palembang belum memahami cara membuat konten promosi digital, beberapa diantaranya bahkan ada yang belum memasarkan produknya pada platform digital seperti melalui facebook dan instagram. Selain itu para peserta UMKM yang telah memiliki akun media sosial seperti facebook dan Instagram sebagai media penjualan online nya masih mengalami kesulitan dalam menggunakan fitur-fitur pada platform digital tersebut untuk mempromosikan produknya, bahkan kadang kala konten promosi yang 
dibuat terkesan monoton dan tidak bervariasi Mayoritas Para Pelaku UMKM yang ada di Kecamatan Ilir Barat II Palembang tidak memiliki strategi untuk membuat konten promosi, mereka hanya mempromosikan produk pada platform digital tanpa ada perencanaan berupa strategi dalam pembuatan konten promosinya. Sehingga dengan adanya pelatihan ini akan dapat meningkatkan pengetahuan dan pemahaman para peserta dalam merancang strategi pembuatan konten promosi digital untuk menarik minat pembelian konsumen dan meningkatkan kembali volume penjualan yang mengalami penurunan akibat dampak pandemi tersebut, sekaligus meningkatkan daya saing nya dalam mempertahankan bisnis di Era New Normal.

\section{SIMPULAN}

Kesimpulan yang dapat diambil dari hasil pelaksanaan kegiatan pengabdian masyarakat ini berdasarkan uraian pembahasan diatas adalah :

1. Sebagian besar para pelaku UMKM di Kecamatan Ilir Barat II Palembang belum memahami strategi pembuatan konten promosi pada platform digital termasuk dalam menggunakan fitur-fitur yang tersedia pada platform media sosial yang dapat dijadikan sebagai tools untuk melakukan promosi digital. Selain itu, sebagian besar dari mereka bahkan tidak menggunakan strategi dalam mendistribusikan konten promosi kepada konsumen karena keterbatasan pengetahuan dan kemampuannya.

2. Dari hasil keseluruhan evaluasi kegiatan pengabdian masyarakat ini dapat diketahui bahwa materi yang disampaikan sangat bermanfaat dalam mengedukasi dan meningkatkan kemampuan para pelaku UMKM yang menjadi peserta pengabdian ini terkait dengan strategi pembuatan konten promosi digital.

3. Dengan adanya kegiatan pengabdian masyarakat ini, para pelaku UMKM yang ada di Kecamatan Ilir Barat II Palembang dapat diberikan edukasi dan pemahaman mengenai teknik dan cara merancang strategi dalam pembuatan konten promosi digital sehingga dapat menarik minat pembelian konsumen dan meningkatkan kembali volume penjualan yang mengalami penurunan akibat dampak pandemi tersebut, sekaligus meningkatkan daya saing nya dalam mempertahankan bisnis di Era New Normal.

\section{UCAPAN TERIMA KASIH}

Penulis mengucapkan terima kasih yang sebesar-besarnya kepada Fakultas Ekonomi Universitas Sriwijaya dan seluruh pihak yang telah mendukung terlaksananya kegiatan pengabdian masyarakat ini baik rekan dosen maupun mahasiswa

\section{REFERENSI}

A. Buku

1) Bank Indonesia. 2008. Undang-Undang Republik Indonesia No.20 Tahun 2008 Tentang UMKM. Jakarta : Bank Indonesia.

2) Kotler, P., Kartajaya, H., Setiawan, I. 2019. Marketing 4.0 Bergerak dari Tradisional Ke Digital. .Jakarta: PT Gramedia Pustaka Utama.

3) Kotler, Philip dan Gary Amstrong. 2018. Principles of Marketing. Edisi 15 Global Edition. Pearson.

4) Kotler, Philip. 2009. Manajemen Pemasaran (Marketing Management) (Edisi 13). U.S.A : Pearson Prentice Hall.

5) Louis E. Boone, David L. Kurtz, 2012. Contemporary Business . Books 14 th edition.

6) Mulyana, D. 2000. Ilmu komunikasi: suatu pengantar. Bandung : Remaja Rosdakarya.

7) Stanton, William J. 2012. Prinsip pemasaran, alih bahasa : Yohanes Lamarto Penerbit Erlangga, Jakarta.

\section{B. Artikel Jurnal}

1) Amalia, suri dan Novianti, ayu. 2016. Pengaruh Bauran Pemasaran Terhadap Kepuasaan Konsumen Pada Warung di Kota Langsa. Jurnal Manajemen Keuangan. Vol.5 No.1.

2) Hasan. 2015. Key Drivers Influencing Shopping Behavior In Retail Stores. 
Journal of Inspiration Economy. Vol. 2(1), 7-33.

3) Kannan, P. K., \& Hongshuang, L. 2016. Digital Marketing: A Framework, Review and Research Agenda. International Journal of Research in Marketing.

4) Kee, A. W. A., Yazdanifard, R. 2015. The Review of Content Marketing as a New Trend in Marketing Practices. International Journal of Management, Accounting, and Economics. ISSN: 23832126 (Online), Vol. 2, No. 9, 2015, hlm. 1055-10.

5) Lestari, Putri dan Saifuddin, Muchammad. 2020. Implementasi Strategi Promosi Produk Dalam Proses Keputusan Pembelian Melalui Digital Marketing Saat Pandemi Covid 19. Jurnal Manova Vol 2. No.2 .

6) Mavilinda, Hera Febria., Nazaruddin., Nofiawaty., Islahuddin \& Dameria, Lina.S. 2021. Penguatan Ekonomi Digital Melalui Pengembangan "Digital Entrepreneurship" Bagi Pelaku UMKM di Desa Kerinjing Ogan Ilir Sumatera Selatan. Selaparang: Jurnal Pengabdian Masyarakat Berkemajuan. Vol.5, No.1.

7) Tresnawati, Yuni dan Prasetyo, Kurniawan. 2018. Pemetaan Konten Promosi Digital Bisnis Kuliner di Media Sosial. Jurnal Unpad, Profesi Humas, Vol.3 No.1 Tahun 2018 Hlm. 102-119.

\section{Sumber Rujukan dari Website}

1) BPS.go.id. 2020. Ekonomi Indonesia Triwulan II 2020 Turun 5,32\%. WWW.BPS.Go.ID. Dilihat 26 September 2020.

https://www.bps.go.id/pressrelease/2020/0 8/05/1737/-ekonomi-indonesia-triwulan-ii2020-turun-5-32-persen.html.
2) Kompas.Tv. com. 2020. Pandemi Corona Pendapatan UMKM Anjlok Hingga 80\%. Kompas TV. Dilihat 26 September 2020. https://www.kompas.tv/article/95049/pand emi-corona-pendapatan-umkm-anjlokhingga-80. Diakses 26 September 2020.

3) Kompas.id. 2020. Sebanyak 12.000 UMKM di Sumsel Terpuruk Akibat Pandemi. Dilihat 26 September 2021. https://kompas.id/baca/nusantara/2020/08/ 25/sebanyak-12-000-umkm-di-sumselterpuruk-akibat-pandemi/.

4) Liputan6.com. 2020. Kemenkop Target 2 Juta UMKM Go Digital Desember 2020. Dilihat 27 September 2020. https://www.liputan6.com/bisnis/read/4279 589/kemenkop-target-2-juta-umkm-godigital-di-desember-2020 .

5) Liputan6.com. 2020. Keberhasilan UMKM Go Digital Masih Rendah. Dilihat 27 September 2020. https://www.liputan6.com/bisnis/read/4279 589/kemenkop-target-2-juta-umkm-godigital-di-desember-2020,

6) Merdeka.com. 2019. Mengenal Platform Pemasaran Digital Untuk Pebisnis Pemula. Dilihat 26 September 2020. https://www.merdeka.com/teknologi/meng enal-platform-pemasaran-digital-untukpebisnis-pemula.html.

7) Watts, Stephen, 2020. Digital Paltform: A Brief Introduction. Dilihat 25 September 2020. https://www.bmc.com/blogs/digitalplatforms/.

8) Tirto.id 2020. Ekonomi Kuartal I 2020 Tersungkur, Indonesia Terancam Resesi. Diakses 26 september 2020. https://tirto.id/ekonomi-kuartal-i-2020tersungkur-indonesia-terancam-resesi-fpp5 